\title{
1294 M. TROJANOVO MŪŠIS
}

\author{
Ričardas Dediala \\ Vilniaus universitetas
}

\section{IVADAS}

Didžiojo kunigaikščio Vytenio valdymo metu (1295-1315 m.) daug kariauta su Vokiečių ordinu, tačiau santykiai su Lenkijos žemėmis taip pat buvo gana intensyvūs. Ši politika tęsẻ Butigeidžio ir Butvydo (Pukuvero) politinę kryptị. Vytenis, didžiojo kunigaikščio Butvydo sūnus, savo politinę karjerą, pasak šaltinių, pradejo lenkų žemių puolimais. Taip viename žygyje ị lenkų žemes jis susidūrẻ su didele priešininkų kariuomene. Šis karinis susidūrimas gavo Trojanovo pavadinimą ir turejjo atgarsị istorijos šaltiniuose. Šaltinių aidas buvo inspiruotas Lenčycos kunigaikščio Kazimiero II (būsimojo Lenkijos karaliaus Vladislovo Uolektinio brolio) mirties mūšio lauke. Vytenio epocha, kaip ir XIII a. 2 pusè - XIV a. pr., nepasižymejjo galingais susidūrimais su lenkų žemių kunigaikščiais, o 1306 m. jie apskritais baigèsi ir atsinaujino jau tik Gedimino laikais, kai pasikeite politinės aplinkybès. Šiame ịvykių fone tampa aktualus šis karinis susidūrimas, atnešęs pergalę didžiajam Lietuvos kunigaikščiui. Paprastai šaltiniai apie šiuos susidūrimus itin skurdūs, daugiausia konstatuojamojo pobūdžio, nesuteikiantys nuodugnesnès analizès galimybès. Šiuo atžvilgiu $1294 \mathrm{~m}$. mūši galètume laikyti tarpiniu variantu, leidžiančiu gan fragmentiškai susipažinti su Trojanovo mūšio aplinkybèmis.

Šio straipsnio tikslas - remiantis istorijos šaltiniais ir istoriografija išanalizuoti 1294 m. Trojanovo mūši. Šiam tikslui igyvendinti užsibrěžème kelis uždavinius: išanalizuoti mūši aprašančius šaltinius, aptarti istoriografijoje (daugiausia lenkiškoje) jau nusistovejjusius teiginius, pateikti naujų su Trojanovo mūšiu susijusių ìžvalgų ir rekonstruoti mūšio aplinkybes. 


\section{ŠALTINIAI IR LITERATŪRA}

Šaltiniai. Trojanovo kautynių atgarsiai pasklidę daugiau nei dešimtyje šaltinių (3 priedas). Plačiausiai mūši aprašantis tekstas pateiktas XIV a. pirmoje pusejje parašytoje Vokiečių ordino brolio ir kunigo Petro Dusburgiečio Prūsijos žemés kronikoje ${ }^{1}$. Ši kronika $1340 \mathrm{~m}$. buvo išversta i vokiečių kalbą ir sueiliuota Ordino didžiųjų magistrų kapeliono Mikalojaus Jerošiniečio ${ }^{2}$. Trojanovo įvykius aprašo ir lenkų istorikas kronikininkas Janas Długoszas (1415-1480), kurio kronikoje Garbingosios Lenkijos karalystès metraščiai arba kronikos (XV a. pab.) pateikiama kiek kitokia negu Petro Dusburgiečio kronikoje mūšio ịvykių interpretacija ${ }^{3}$. J. Długoszo tradicija seke ir Motiejus Miechovietis (1457-1523) ${ }^{4}$. Kitas svarbus šaltinių pluoštas - lenkų metraščiai, kuriuose tik pažymimas pats mūšio faktas, minimi žuvusieji ir kartais kai kurios aplinkybès. Tokią informaciją pateikia Krokuvos pranciškony (XIII a. pab.) ${ }^{5}$, Miechovo (XIV a.) ${ }^{6}$, Traskos (XIV a. I pusès) ${ }^{7}$, Mažosios Lenkijos ${ }^{8}$, Lenku kunigaikščiu kilmés (XV a.) metraščiai ${ }^{9}$, taip pat Gniezno pastabos (XIV a. pr.) ${ }^{10}$, Lenku kunigaikščiu kronika (XIV a. pab.) ${ }^{11}$. Apie Trojanovo mūši užsimenama ir XVII a. kompiliaciniame Gustyno metraštyje ${ }^{12}$.

1 Petri de Dusburg Chronicon terrae Prussiae // Scriptores rerum Prussicarum (toliau SRP), 1861, Bd. 1, s. 176-177; Petras Dusburgietis. Prūsijos žemės kronika. Vilnius, 1985, p. 228-229.

2 Di Kronike von Pruzinlant des Nicolaus von Jeroschin // SRP, 1861, Bd. 1, s. 534-535 (lin. 19886-19977).

3 J. Dlugosz. Historiae Polonicae libri XII, t. 2, s. 520-521.

4 Mathias de Miechow. Chronica Polonorum. Cracoviae, 1521, lib. 3, cap. 65, fol. 190.

5 Rocznik franciszkański krakowski // Monumenta Poloniae Historica (toliau - MPH), 1961, t. 3, s. 47.

6 Rocznik miechowski // MPH, 1961, t. 2, s. 883.

7 Rocznik Traski // MPH, 1961, t. 2, s. 852.

8 Rocznik małopolski // MPH, 1961, t. 3, s. 186.

9 Rodowód xiążąt polskich // MPH, 1961, t. 3, s. 283.

10 Spominki gnieźnieński // MPH, 1961, t. 3, s. 43-44.

11 Kronika xiążąt polskich // MPH, 1961, t. 3, s. 542-543.

12 Густинская летопись // Полное собрание русских летописей (toliau - ПСРЛ), 1843 , т. 2 , с. 348. 
Literatūra. Itvairūs Trojanovo mūšio aprašymai, dažniausiai parengti remiantis Petru Dusburgiečiu ir Janu Długoszu, pateikiami daugelyje ịvairių istorikų darbų. Jị mini Motiejus Strijkovskis ${ }^{13}$, Aleksandras Guagninis ${ }^{14}$, Martynas Bielskis ${ }^{15}$, Albertas Vijūkas-Kojelavičius ${ }^{16}$, Simonas Daukantas ${ }^{17}$ ir Teodoras Narbutas ${ }^{18}$.

Šaltinius suregistravo ir ịžvalgas apie kautynes pateikè Henrykas Paszkiewiczius $^{19}$. Trojanovo mūšis išsamiausiai buvo aptartas Lenkijos istorikų Kazimierzo Aściko ir Stanisławo Zajączkowskio XX a. septintajame dešimtmetyje. Tarp šių dviejų istorikų kilo arši diskusija dèl ịvairių mūšio aspektų $^{20}$. Vèlesnè lenkų ir lietuvių istoriografija seké šių autorių išvadomis. Lenčycos ir Sieradès žemių vaidmenį kariniuose konfliktuose XII-XIII a. aptarė Janas Szymczakas²1. Adamas Szweda analizavo lietuvių ìvykdytus Dobrynès žemės antpuolius XIII a. pab. - XIV a. pr. ${ }^{22}$ Plačiau mūšĭ ana-

13 Stryjkowski M. Kronika Polska, Litewska, Żmódzka i wszystkiej Rusi. Warszawa, 1846, t. 2, s. 338 .

14 Z kroniki Sarmacyi europskiekiej Alexandra Gwagnina z Werony: opisane Polski, W. Ks. litewskiego, ziemie ruskiej, ziemie pruskiej, ziemie inflantskiej, ziemie żmudzkiej. Kraków, 1860, s. 68-69.

15 Kronika Marcina Bielskiego. Sanok, 1856, t. 3, s. 347-348.

16 Vijūkas-Kojelavičius A. Lietuvos istorija. Vilnius, 1988, p. 630-635.

17 Daukantas S. Istorija žemaitiška. Vilnius, 1995, t. 1, p. 481-482.

18 Narbutas T. Lietuvių tautos istorija. Vilnius, 1997, t. 4, p. 299-300.

19 Paszkiewicz H. Jagiellonowie a Moskwa: Litwa a Moskwa w XIII i XIV wieku. Warszawa, 1933, t. 1, s. 157-158; Paszkiewicz H. Regesta Lithuaniae: ab originale usque ad Magni Ducatus cum Regno Poloniae Unionem. Tempora usque ad annum 1315 complectens. Varsoviae, 1930, t. 1, s. 147 (nr. 718).

20 Aścik K. Najazd litewski na Łęczycę w 1294 r. // Studia i materiały do historii wojskowości, 1964, t. 10, cz. 1, s. 3-11 (ịvairių autorių fragmentišką literatūros apžvalgą, kurioje mūšis yra tik paminètas, bet ne analizuotas, K. Aścikas pateikia 1-17 nuorodose); Zajączkowski S. W sprawie najazdu litewskiego na Łęczycę w 1294 r. // Studia i materiały do historii wojskowości, 1966, t. 10, cz. 2, s. 321-331; Aścik K. Jeszcze raz o najeździe litewskim na Łęczycę // Studia i materiały do historii wojskowości, 1969, t. 15, cz. 1, s. 317-321.

21 Szymaczak J. Ziemia łęczycka i sieradzka terenem działań wojennych w XII i XIII wieku // Rocznik Łódzki 1975, t. 20(23), s. 199-225.

22 Szweda A. Najazdy litewskie na ziemię dobrzyńską na przełomie XIII/XIV w. // Zeszyty Historyczne WSP w Częstochowie, 1996, t. 3, s. 83-94. 
lizavo, aptardamas lenkų ir lietuvių santykius, Grzegorzas Błaszczykas ${ }^{23}$, reziumavęs, kad tai buvo tragiškiausias lenkų žemèms lietuvių puolimas ${ }^{24}$. Fragmentiškai apie mūši užsimenama disertacijos pagrindu parengtoje ir 2004 m. išleistoje lenkų istoriko Dariuszo Prekopo monografijoje, skirtoje Ordino karui su Lietuva $1283-1325$ m. ${ }^{25}$

Lietuviškoje istoriografijoje šiam mūšiui nebuvo skirta ypatingo dèmesio, todèl jis mažiau žinomas. Iki šiol plačiausią mūšio apžvalgą pateikè karo istorijos populiarintojas Zigmas Raulinaitis ${ }^{26}$. Naujausioje istoriografijoje išsamiausiai mūšs̆ aptare Artūras Dubonis, pateikdamas glaustą XIII a. pab. - XIV a. pr. santykiu su lenkais apžvalgą ${ }^{27}$. Tik vienu sakiniu apie ši susidūrimą informuoja Zenonas Ivinskiss ${ }^{28}$, politinę situaciją fragmentiškai nušviečia Stephenas C. Rowellas ${ }^{29}$ ir Edvardas Gudavičius ${ }^{30}$, Alvydas Nikžentaitis ${ }^{31}$, pergalę prie Trojanovo, kaip didžiausią Lietuvos karinę pergalę prieš lenkus, pažymi Tomas Baranauskas ${ }^{32}$.

${ }^{23}$ Błaszczyk G. Dzieje stosunków polsko-litewskich od czasów najdawniejszych do współczesności. Poznań, 1998, t. 1, s. 53-55.

${ }^{24}$ Ten pat, s. 53.

25 Prekop D. Wojna zakonu krzyżackiego z Litwą w latach 1283-1325. Toruń, 2004, s. 80.

${ }^{26}$ Raulinaitis Z. Lietuvos raiteliai. Kn. 5: Pakeliui ị galią. Vilnius, 1999, p. 179-183.

27 Dubonis A. Santykiai su kaimynais Vakaruose // Lietuvos istorija XIII a. - 1385 m. Valstybès iškilimas tarp Rytų ir Vakarų. Baronas D., Dubonis A., Petrauskas R. Vilnius, 2011, p. 488.

${ }^{28}$ Ivinskis Z. Lietuvos istorija. Iki Vytauto Didžiojo mirties. Roma, 1978, p. 215.

${ }^{29}$ Rowell S. C. Iš viduramžių ūkų kylanti Lietuva: pagonių imperija Rytų ir Vakarų Europoje, 1295-1345. Vilnius, 2001, p. 59-61.

${ }^{30}$ Gudavičius E. Lietuvos istorija. Vilnius, 1999, t. 1, p. 77.

${ }^{31}$ Nikžentaitis A. Nuo Daumanto iki Gedimino: Ikikrikščioniškos Lietuvos visuomenès bruožai // Acta historica universitatis Klaipedensis. Vilnius, 1996, t. 5, p. 104; Nikžentaitis A. Vytenis // Iš kur atėjome. Kaunas, 1988, p. 27.

32 Tūkstantmečio knyga. Sud. D. Baltrušienè. Vilnius, 1999, t. 1, p. 18. 


\section{POLITINĖ LDK SITUACIJA PRIEŠ MŪŠI}

Santykiai su lenkais XIII a. pab. rutuliojosi gana intensyviai ${ }^{33}$. Lietuviu žygių i lenkų žemes problematika labai sudètinga, nes itin sunku suprasti tikslus - grobiamieji jie ar politiniai, - kuriais vadovavosi puolantieji. Lietuvių kišimasis ị Lenkijos vidaus reikalus ịvèlè daug neaiškumų, nes itempta situacija Lenkijos viduje vertẻ lenkų žemių kunigaikščius manevruoti, ieškoti, kaip kuo palankiau išnaudoti Lietuvos karinị potencialą. Tuo pat metu intensyviai kariauta su Vokiečių ordinu, kuris 1283 m. nukariavo jotvingius ir atsidūrè prie Lietuvos sienos. Tad Vytenio valdymo pradžioje išryškèjo dvi svarbios kryptys: Lenkijos žemè ir Vokiečių ordinas (prūsiškoji šaka), o pačioje XIII a. pab. - aktualus Rygos ir Livonijos konfliktas, ì kurị sẻkmingai įsitraukẻ Lietuvos didysis kunigaikštis ir aktyviai vykdẻ diplomatinę ir karinę politiką Vokiečių ordino livoniškosios šakos kryptimi. XIV a. pr. Vokiečių ordino prūsiškosios šakos aktyvūs veiksmai prieš Lietuvos Didžiąją Kunigaikštystę privertẻ Vytenį nuo 1306 m. nutraukti žygius į Lenkiją ir susitelkti karo su kryžiuočiais fronte ${ }^{34}$.

1279 m. už Mazovijos kunigaikščio Boleslovo II ištekinta Gaudimante Traidenytè, kuri pasikrikštijo Sofijos vardu, mirẻ $1288 \mathrm{~m}$. (pagimdẻ Siemovitą II, Trojdeną I ir šaltiniuose neịvardytą dukterị) ${ }^{35}$. Taip Mazovija tapo apsaugota nuo lietuvių antpuolių ${ }^{36}$. Glaudūs santykiai su šios lenkų žemès kunigaikščiu buvo palaikomi net ir po Gaudimantès mirties, nepaisant to, kad $1291 \mathrm{~m}$. (iki $1302 \mathrm{~m}$.) Boleslovas II vedè čekų karaliaus Vaclovo II seserị Kunigundą.

XIII a. devintajame dešimtmetyje buvo keičiamas santykių su Lenkijos žemèmis pobūdis. Tai, ko gero, inicijavo Butigeidis su Butvydu. Buvo pasitraukta iš Mazovijos kunigaikščių vaidų ir susitaikyta su Traidenio žentu

\footnotetext{
33 Gudavičius E. Lietuvos istorija. Vilnius, 1999, t. 1, p. 77.

34 Szweda A. Najazdy litewskie na ziemię dobrzyńską na przełomie XIII/XIV w., p. 89; Dubonis A. Santykiai su kaimynais Vakaruose, p. 489; Błaszczyk G. Dzieje stosunków polsko-litewskich..., s. 58.

35 Dubonis A. Traidenis. Monarcho valdžios atkūrimas Lietuvoje 1268-1282 m. Vilnius, 2009, p. 178; Dubonis A. Meilè ir politika. Traidenis tekina dukterị // Darbai ir dienos, 2005, t. 44, p. 27.
}

36 Dubonis A. Meilè ir politika, p. 28. 
po trumpos santykių suirutès po Traidenio mirties ${ }^{37}$. Net ir atsisakęs pretenzijų i sostą Vladislovo Uolektinio naudai, Mazovijos kunigaikštis toliau palaikè glaudžius ryšius su sąjungininkais pagonimis ${ }^{38}$. Lietuviai, aiškiai turẻdami politinių tikslų, $1302 \mathrm{~m}$. žygiavo ị Lenkiją paremti Boleslovo II ir lenkų pretendento ị Krokuvos sostą Vladislovo Uolektinio, kuris tuo

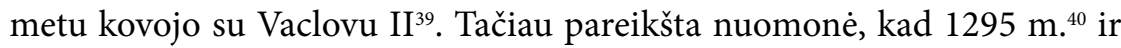
1296 m. ${ }^{41}$ šie veiksmai taip pat galejo būti nukreipti prieš Pšemislų dinastijos ịsigalejimą ${ }^{42}$, nors istoriografijoje teigiama, kad tai buvę paprasčiausi lietuvių plèšikèlių (lot. latrunculi) būriai, kurių žygiai nèra aiškiai susiję su politika $^{43}$.

Apskritai nuo 1292 iki 1306 m. (pirmojo ir paskutinio Vytenio laiku žygio ị lenkų žemes) surenti 8 žygiai, kurių tikslas buvo: 1292 m. - Kujavijos Brestas, 1294 m. - Lenčyca, 1295 m. ir 1296 m. - Sandomiero žemé, 1300 m. - Dobrynė ir Kulmas, 1302 m. - Varka (Sandomieras), 1305 m. Kališas ir Stavišinas, 1306 m. - Kališo apylinkès ir nusiaubta Sieradzès žemè $\dot{4}^{44}$. Dar Traidenio laikų politika prieš Ordinui palankias lenkų kunigaikštystes ${ }^{45}$ matyti Vytenio laikų žygiuose, tačiau itin sudètingos politinès aplinkybès leidžia tik hipotetiškai ịvardyti tikruosius antpuolių siekius.

\footnotetext{
37 Dubonis A. Santykiai su kaimynais Vakaruose, p. 488.

38 Rowell S. C. Iš viduramžių ūkų kylanti Lietuva, p. 61.

39 Dubonis A. Santykiai su kaimynais Vakaruose, p. 489.

40 Rocznik Traski // MPH, 1961, t. 2, s. 853: „1295. [...] Eodem anno Litwani vastaverunt usque in Gnoyno."

41 Ten pat, s. 853: „1296. [...] Litwani terram Sandomiriensem intrant et vincuntur.“

42 Szweda A. Najazdy litewskie na ziemię dobrzyńską na przełomie XIII/XIV w., p. 88. Jeigu istoriko hipotezè teisinga, Kunigunda netrukdẻ Boleslovui II veikti prieš čekus, o pati greičiausiai atsidūrè politinès ịkaitès vietoje, nes realiai neturejo jokios galios, tad, kaip pats istorikas teigia, ši santuoka buvo laikina.

43 Błaszczyk G. Dzieje stosunków polsko-litewskich..., s. 55-56; Dubonis A. Santykiai su kaimynais Vakaruose, p. 488.

44 Błaszczyk G. Dzieje stosunków polsko-litewskich..., s. 50-58; Dubonis A. Santykiai su kaimynais Vakaruose, p. 488-489.

45 Szymaczak J. Ziemia łęczycka i sieradzka terenem działań wojennych w XII i XIII wieku, s. 215; Szweda A. Najazdy litewskie na ziemię dobrzyńską na przełomie XIII/XIV w., p. 85 .
} 
1292 m. žygis - Vytenio politinès karjeros pradžia. Butvydo sūnus vadovavo žygiui ị Kujavijos Bresto kunigaikštystę. Nusiaubẻ kraštą, paemė ị nelaisvę žmonių. Kazimieras II ir Vladislovas Uolektinis kreipèsi pagalbos ì Prūsijos magistrą Menhardą Kverfurtietị, ir šis atsivedè didelę kariuomenę. Lenkų ir kryžiuočių koalicija nesugebejjo pasipriešinti Vyteniui. Kronikininkas Petras Dusburgietis pažymi, kad lenkai pabėgo iš mūšio lauko, o tai pamatę Ordino kariai taip pat pasileido bėgti ${ }^{46}$. Panašu, kad žygis užgriebė Dobrynès žemę, nes ị nelaisvę buvo paimtas kunigaikštis Siemovitas (Kazimiero II brolis), kuris joje buvo laikomas $1292-1296$ m. ${ }^{47}$ Dobrynè nukentejjo antrą kartą, kaip jau minèta, $1300 \mathrm{~m}$. Lietuviai pasieké ir Ordino Kulmą, bet pralaimejo kautynes. Galimas šio puolimo motyvas buvo Siemovito palankumas kryžiuočiams ${ }^{48}, 1305 \mathrm{~m}$. šis kunigaikštis, bijodamas lietuvių antpuolių, padovanojo Ordinui žemių ${ }^{49}$. Tokia Lietuvos didžiojo kunigaikščio politika vertè lenkų kunigaikščius likti neutralius arba ieškoti pagalbos. Visų šių ịvykių sūkuryje lietuviai naudojosi Mazovijos kunigaikščio Boleslovo II Viznos pilimi. Ją Vokiečių ordinas sugriovè, bet lietuviai pili $1295 \mathrm{~m}$. kartu su lenkais atstate் $\dot{e}^{50}$.

$1294 \mathrm{~m}$. žygis ị Lenčycos pusę skendi motyvų migloje, leidžiančioje tik hipotetiškai spręsti apie pirminius valdovo sumanymus ir netikètus jų pasikeitimus žygio metu.

\section{TROJANOVO MŪŠIO ANALIZE்}

Istoriografijoje susiklostẻ kontroversiška šio žygio dviejų aspektų vertinimo tradicija. Pirmoji susijusi su žygio maršrutu, antroji - su Boleslovo II vaidmeniu šiuose ịvykiuose. Vytenio žygio maršruto aiškinimo polemiką

\footnotetext{
46 Petri de Dusburg Chronicon terrae Prussiae // SRP, 1861, Bd. 1, s. 155-156.

47 Szweda A. Najazdy litewskie na ziemię dobrzyńską na przełomie XIII/XIV w., p. $86-87$.

48 Dubonis A. Santykiai su kaimynais Vakaruose, p. 488.

49 Szweda A. Najazdy litewskie na ziemię dobrzyńską na przełomie XIII/XIV w., p. 89.

50 Petri de Dusburg Chronicon terrae Prussiae // SRP, 1861, Bd. 1, s. 160.
} 
G. Błaszczykas apibūdino kaip itin hipotetinę $e^{51}$. Reikia sutikti su šia istoriko išvada, nes jokie šaltiniai nieko konkretaus nepasako apie maršruto eigą, o tik nurodo orientacines vietas. K. Aściko ir S. Zajączkowskio ginčas ìvėlè daug neaiškumų, tačiau hipotezèmis paremtos interpretacijos bendroje mūšio analizèje daugiau poleminès. S. Zajączkowskis teigè, kad žygis prasidejo iš Gardino pusès. Tuomet Vytenio pajègoms reikèjo persikelti per Vyslą prie Vyšegrado (šią versiją palaikè J. Szymaczkas (2 priedas)) ${ }^{52}$, nes pirminis tikslas buvo Kulmas. Ši puolimo versija argumentuojama $1294 \mathrm{~m}$. birželio 8 d. datuojamu Kulmo žemès komtūro vietininko laišku, kuriame užsimenama apie galingas pagonių pajègas, traukiančias ị Kulmo žemès pusę ${ }^{53}$. S. Zajączkowskis šias pajègas priskyrè būtent Vyteniui ${ }^{54}$. Tokiu būdu pirminè idèja buvo smogti Vokiečių ordino žemei, ten paplèšikauti. Tačiau, sprendžiant iš laiško turinio, žvalgai jau žinojo apie Vytenio pajègų judejimą, todèl, matyt, Vytenis privalèjo pakeisti pirminị sumanymą ir žygiuoti kitur. Taigi, pasikeitus maršrutui, žygiuota toliau per Boleslovo II valdas, o per Vyslos upę persikelta tarp Plocko ir Vyšegrado. Tada palei Bzuros upę nueita iki Lenčycos ${ }^{55}$. K. Aścikas, iš esmès nekreipdamas dėmesio ị Kulmo aspektą, žygio maršrutą vaizdavo taip: Vytenis kirto Nemuną ir žygiavo pasienio miškais tarp Lietuvos, Prūsijos ir Mazovijos ${ }^{56}$. Paskui prie Zakročymo perèjo Vyslą. Vèliau prie Trojanovo persikèlè per Bzurą, o tarp Sabotos ir Valevičių - ị dešinijji Bzuros krantą ir atsidūrẻ ant Lovičiaus-Tumo kelio, juo ir nužygiavo iki Lenčycos (1 priedas) ${ }^{57}$. Opo-

51 Błaszczyk G. Dzieje stosunków polsko-litewskich..., s. 55.

52 Szymaczak J. Ziemia łęczycka i sieradzka terenem działań wojennych w XII i XIII wieku, s. 222.

53 Preussisches Urkundenbuch, Bd. I, 2, hrsg. von A. Seraphin. Königsberg, 1909, nr. 628, s. 399: „[...] duos nuncios commendatoris de Schonense de solitudine venisse, qui dicunt, quod magnus et validus exercitus paganorum [paryškinta mano - R. D.] procedat versus terram Chulmensem et ob metum illorum omnes, qui sunt in terra Mazouie, fugerunt ad municiones. “ Šis laiškas rodo, kad Mazovijos gyventojai nežinojo apie Boleslovo II susitarimą su lietuviais, nes jiems pastarieji kèlè baimę.

54 Zajączkowski S. W sprawie najazdu litewskiego na Łęczycę w 1294 r., s. 324 . H. Paszkiewiczius šiuos duomenis vertino kaip svarbius, bet konkretesnių išvadų nepadarè. Žr.:

Paszkiewicz H. Jagiellonowie a Moskwa, s. 157 (5 nuoroda).

55 Zajączkowski S. W sprawie najazdu litewskiego na Łęczycę w 1294 r., s. 325.

56 Aścik K. Jeszcze raz o najeździe litewskim na Łęczycę, s. 327.

57 Ten pat, s. 317-319. 
nuodamas S. Zajączkowskiui, jis teigè, kad prie Vyšegrado keltis nebuvo imanoma, nes tose vietose upès krantai yra labai statūs ${ }^{58}$. Taigi susiformavo Vyslos perèjimo prie Vyšegrado ir Zakročymo versijos, tačiau žygio maršrutui aktualesnė vieta, iš kurios prasidejo žygis. Gardino žygio pradžia hipotetinè, tačiau galima, nes taip lenkų žemes pasiekti būtų buvę lengviau, negu žygiuoti per Ordino užvaldytas Prūsijos ar Jotvos teritorijas.

1294 m. per Sekmines (birželio 6-7 d.) ${ }^{59}$ Vytenio vadovaujamos pajègos ịsiveržè i̇ Lenčycos kunigaikštystę. G. Błaszczykas, visiškai pasitikèdamas J. Długoszo informacija apie Vytenio pajègų sudètí, teigè, kad Vytenio 800 karių kariuomenę sudarẻ lietuviai, prūsai ir žemaičiai ${ }^{60}$. Tačiau tai - tik J. Długoszo pateiktos unikalios žinios ${ }^{61}$, jų nèra ankstyvesniuose šaltiniuose ${ }^{62}$, kaip ir 1800 užpuolikų skaičiaus ${ }^{63}$. Priešingai, Petras Dusburgietis 1800 vyrų priskyrè ne Vytenio pusei, o Kazimiero II pajègoms ${ }^{64}$. Šiuo atveju aiškus J. Długoszo manipuliavimas skaičiais, kurio priežastis buvo negalejjimas sutikti su tuo, kad netikèliai pagonys galèjo ịveikti lenkų kunigaikštị ir jo atvestus karius ${ }^{65}$. Vytenio Lenčycos užpuolimas buvo netikè-

\footnotetext{
58 Ten pat, s. 319.

59 Petri de Dusburg Chronicon terrae Prussiae // SRP, 1861, Bd. 1, s. 156: „[...] et in die pentecostes [...]“. Atkreiptinas dèmesys, kad Gniezno pastabose įvykiai datuojami $1304 \mathrm{~m}$. (Spominki gnieźnieński // MPH, 1961, t. 3, s. 43: „[...] anno 1304 die penthecostes.“). Ši klaida ịsivèlè datą užrašant romeniškais skaitmenimis: vietoje MCCXCIV buvo užrašyta MCCCIV, t. y. praleistas X, ir išèjo 1304 m. Žr.: Balzer O. Genealogia Piastów. Kraków, 1895 , s. 343.
}

60 Błaszczyk G. Dzieje stosunków polsko-litewskich..., s. 53.

61 J. Dlugosz. Historiae Polonicae libri XII, t. 2, s. 520: „Vithenen enim Lithuaniae Dux cum mille octingentis equitibus, ex Lithuanis, Pruthenis et Samagitis collectis, in Lanciciensem terram impetum fecit."

62 Aścik K. Najazd litewski na Łęczycę w 1294 r., s. 5. Galima papildyti, kad 1287 m. Dobrynės žemès puolime J. Dlugoszas lietuvių pajègas apibūdina taip pat, t. y. lietuviai, prūsai, žemaičiai. Neaišku, apie kokius prūsus kalba J. Dlugoszas, nes prūsai iki šio mūšio jau buvo nukariauti. Manytume, kad tai - literatūrinis topas, neturintis realaus pagrindo. 63 J. Dlugosz. Historiae Polonicae libri XII, t. 2, s. 520: „[...] cum mille octingentis equitibus $[\ldots]$...

64 Petri de Dusburg Chronicon terrae Prussiae // SRP, 1861, Bd. 1, s. 156: „Casimirus dux Polonie dolens de suorum interitu, cum mille et octingentis viris sequutus est eos.“

${ }^{65}$ Aścik K. Jeszcze raz o najeździe litewskim na Łęczycę, s. 321. 
tas, nes pasirinktas bažnytinės šventès laikas ${ }^{66}$, kai Lenčycos kanauninkai, kunigai, apsivilkę iškilmių arnotais, èjo procesijoje. Vytenio pajėgos juos užpuole ir 400 asmenų, t. y. prelatus, kunigus ir kitus, buvusius bažnyčioje, Petro Dusburgiečio žiniomis, paprasčiausiai nužude் ${ }^{67}$. Svarbesnị turtą (taures, bažnytinius indus) pagrobè, sudegino bažnyčią. Vèliau nusiaubė apylinkes ir susirinkę visus paimtus į nelaisvę žmones nusprendè pasidalyti - taip kiekvienam teko po 20 krikščionių ${ }^{68}$. Abejotina ir ši Petro Dusburgiečio žinia, nes tada Lenčycos apylinkèse Vytenio kariai turèjo suvaldyti 16000 žmonių, neskaitant paimto grobio. Didinant skaičius paprastai buvo siekiama didesnio ịspūdžio, parodyti krikščionybès priešų netikèlių pagonių žiaurumą.

Vytenis su savo pajėgomis pajudejo atgal link Trojanovo, tačiau suspejęs sutelkti pajėgas Lenčycos kunigaikštis Kazimieras II pasileido vytis užpuolikus su 1800 vyrų $^{69}$. J. Długoszas šioje vietoje ir, matyt, tyčia siekdamas pateikti Kazimiero II pajėgas kaip mažesnes, akcentavo jų negausumą, palyginti su Vytenio kariuomene ${ }^{70}$. Lenkų pajègos didžiojo kunigaikščio sūnaus karius pavijo prie Sochačevo, Bzuros upès, tiksliau - Trojanovo ir

661311 m., prieš pat Voplaukio mūšĭ, Vytenis puolè Prūsiją Didžiąją savaitę. Šis laikas, be abejo, galejo būti pasirinktas atsitiktinai, tačiau strategine prasme tokiu metu įsiveržti buvo itin palanku, todèl orientavimasis ị katalikiškas šventes turètų būti vertinamas kaip pagoniškos karinès taktikos dalis. Žr.: Dediala R. 1311 m. Voplaukio mūšis: priežastys, eiga, karybos aspektai, istorinė atmintis // Karo archyvas, 2015, t. 30, p. 29.

67 Šiuo atveju abejotina, ar bažnyčioje būtų susirinkę 400 žmonių, tačiau svarbu atkreipti dèmesị i Dariaus Barono pastabą apie dvasininkų žudymą. Istoriko manymu, XIII a. kontekste šaltiniuose pasitaikantys ịvairūs duomenys apie dvasininkų žudymą baltų visuomeneje rodo tvirtą vyro ir kario tapatybès ịsišaknijimą. Žr.: Baronas D. Lietuvių karyba XIII a. // Karo archyvas, 2000, t. 16, p. 8-9.

68 Petri de Dusburg Chronicon terrae Prussiae // SRP, 1861, Bd. 1, s. 156-157; Di Kronike von Pruzinlant des Nicolaus von Jeroschin // SRP, 1861, Bd. 1, s. 534 (lin. 1988619941); Petras Dusburgietis. Prūsijos žemès kronika, p. 228-229.

69 Petri de Dusburg Chronicon terrae Prussiae // SRP, 1861, Bd. 1, s. 156: „[...] cum mille et octingentis viris [...] “; Di Kronike von Pruzinlant des Nicolaus von Jeroschin // SRP, 1861, Bd. 1, s. 534 (lin. 19951): „[...] mit achzênhundirt mannen.“

70 J. Dlugosz. Historiae Polonicae libri XII, t. 2, s. 520: „[...] consecutus fuisset, paucitate sui agminis et hostili multitudine minime pensata $[\ldots]^{\prime \prime}$. 
Žukovo apylinkèse ${ }^{71}$, kurios buvo miškingos ir pelkètos ${ }^{72}$. Čia netikètai ịsikišo Mazovijos kunigaikštis Boleslovas II, kuris, kronikininkų nuostabai, sudarè paliaubas tarp pagonių ir krikščionių. Ši Mazovijos kunigaikščio epizodą J. Długoszas ignoruoja, o tik mini, kad Boleslovas II praleido lietuvius dar žygio ị Lenčycą metu, bet apie tolesnị tarpininkavimą neužsimena $^{73}$. Boleslovas II, matyt, tuo metu buvęs savo pilyje Sochačeve $e^{74}$, suvaidino tarpininko vaidmenį, norèdamas išlikti neutralus. Taip laviruodamas jis rado išeiti, kuri, matyt, leido ne tokioms gausioms Vytenio pajègoms persigrupuoti ir pasiruošti puolimui ${ }^{75}$. Žinoma, kad užklupti su grobiu lietuviai (būtent grobiamuoju žygiu Trojanovą vadina lenkų istorikai) ${ }^{76}$, traukiantys atgal iš apiplěšto krašto, nerodydavo didelio kovingumo, greičiau siekdavo išvengti mūšio, nes grobis ir belaisviai varžydavo žygiuojančių veiksmus $^{77}$. Netikètai šias paliaubas ${ }^{78}$ lietuviai nutraukè ir užpuolè nepasiruošusius Kazimiero II karius ${ }^{79}$. Istoriografijoje teigiama, kad mūšis ịvyko

71 J. Dlugosz. Historiae Polonicae libri XII, t. 2, s. 520: „Quos cum in Zukov villa, prope oppidum Sochaczow supra fluvium Bszura sita, secundum alios circa villam Troyanow $[\ldots]^{\text {“. }}$

72 Aścik K. Najazd litewski na Łęczycę w 1294 r., s. 9.

73 J. Dlugosz. Historiae Polonicae libri XII, t. 2, s. 520.

74 Zajączkowski S. W sprawie najazdu litewskiego na Łęczycę w 1294 r., s. 325.

75 Aścik K. Najazd litewski na Łęczycę w 1294 r., s. 9.

76 Szymaczak J. Ziemia łęczycka i sieradzka terenem działań wojennych w XII i XIII wieku, s. 224; Aścik K. Najazd litewski na Łęczycę w 1294 r., s. 7.

77 Baronas D. Lietuvių karyba XIII a. // Karo archyvas, 2000, t. 16, p. 12.

78 Atkreiptinas demesys ị vieną aspektą: 1295 m. lapkričio 24 d. dokumente, skirtame Bialos pilininkui Laurynui, kalbama apie pastarojo suteiktą pagalbą Boleslovui II, kilus užpuolimo pavojui (Kodeks dyplomatyczny Księstwa Mazowieckiego. Warszawa, 1863, nr. 41, s. 32). Be to, $1302 \mathrm{~m}$. fundacijoje dominikonams Boleslovas II mini pagonių nusiaubtą Mazoviją (ten pat, nr. 46, s. 35-36). Vis dèlto, kaip pažymėta istorikų, šie duomenys prieštarauja mūšio aprašymui, nes čia nèra jokios užuominos, kad Mazovijos kunigaikščiui būtų kilusi kokia nors grèsmė. Galejo būti kalbama apie chronologiškai kitus ịvykius (Zajączkowski S. W sprawie najazdu litewskiego na Łęczycę w 1294 r., s. 327). Remdamasis anksčiau išvardytais šaltiniais K. Aścikas neigė Boleslovo II bendradarbiavimą su Vytenio pajègomis (Aścik K. Najazd litewski na Łęczycę w 1294 r., s. 10), tačiau tai niekaip nepaaiškina Boleslovo II lietuviams naudingo tarpininkavimo prieš mūṣ̨̌ ir žinių apie Viznos pili, kurias pateikia kronikininkas Petras Dusburgietis.

79 Petri de Dusburg Chronicon terrae Prussiae // SRP, 1861, Bd. 1, s. 157. K. Aścikas pateikè pasvarstymą, esą paliaubos galbūt buvo nutrauktos lenkų iniciatyva, nes jie manė 
birželio 10 d., tačiau šaltiniuose tiksli data nenurodyta. Hipotetiškai mūšis galejjo vykti ir birželio 9, ir $10 \mathrm{~d}{ }^{80}$ Taip ìsiplieskè kautynès prie Trojanovo. Jos, ko gero, vyko, istorikų teigimu, naktị, pelkių ir miškų apsuptyje, dešiniajame Bzuros krante ${ }^{81}$. Šių ịvykių sūkuryje Vytenio pajègos sutriuškino Kazimiero II kariuomenę. J. Długoszo tvirtinimu, kariai skendo Bzuros upeje ${ }^{82}$. Žuvo ir pats Lenčycos kunigaikštis Kazimieras II, o jo mirties faktas pateko ị daugeli šaltinių ${ }^{83}$. Gyvas liko tik vienas karys, kuris pasprukęs papasakojo apie ši lenkų kariuomenès fiasko ${ }^{84}$.

Kas lèmė Vytenio pajègų sẻkmę? K. Aścikas ịvardijo keletą priežasčių: 1) netikètas lietuvių puolimas; 2) Kazimiero II kovų su lietuviais patirties stoka; 3) lietuviškos karybos taktikos neišmanymas. Trečiasis argumentas remiamas tuo, kad lietuvių išmintingiau buvo parinktas mūšio laukas, nes Bzuros upès apylinkès buvo pelkètos, o lenkų kavalerijos žirgai nebuvo pajègūs kovoti tokioje teritorijoje, todèl ju pajègos ir buvo sumuštos ${ }^{85}$. Nors ši teorija karinès taktikos prasme ịdomi, kyla nemažai abejonių dèl tokios ìvykių eigos. Istorikui atrodè, kad lenkai neišmanè lietuvių karybos takti-

turị didesnę persvarą. Vis dèlto ši įvykių eiga prieštarautų paties K. Aściko tyrimui, nes tada tai būtų nutikę iš karto, dar nespejjus Vytenio atvestoms pajègoms persigrupuoti ir užsiimti geresnes pozicijas, ką lenkų istorikas ypač pabrěžia. Žr.: Aścik K. Jeszcze raz o najeździe litewskim na Łęczycę, s. 320.

80 Osvaldo Balzerio tyrimas (Balzer O. Genealogia Piastów. Kraków, 1895, s. 344.) rodo, kad mirties data veikiausiai buvo birželio $10 \mathrm{~d}$. Šitokia išvada daroma atsižvelgiant i Gniezno pastabu užuominą: Spominki gnieźnieński // MPH, 1961, t. 3, s. 44: „Eodem anno quinta feria proxima post festum penthecostes [...]“.

81 Aścik K. Najazd litewski na Łęczycę w 1294 r., s. 9.

82 J. Dlugosz. Historiae Polonicae libri XII, t. 2, s. 520.

83 Petri de Dusburg Chronicon terrae Prussiae // SRP, 1861, Bd. 1, s. 157; Spominki gnieźnieński // MPH, 1961, t. 3, s. 44; Rocznik franciszkański krakowski // MPH, 1961, t. 3, s. 47; Rocznik małopolski // MPH, 1961, t. 3, s. 186; Rodowód xiążąt polskich // MPH, 1961, t. 3, s. 283; Rocznik miechowski // MPH, 1961, t. 2, s. 883; Густинская летопись // ПСРЛ, 1843, т. 2, с. 348. Dviejuose šaltiniuose - Gniezno pastabose ir J. Dlugoszo Istorijoje - nurodyti ne 1294, o 1304 m. (Spominki gnieźnieński // MPH, 1961, t. 3, s. 44; J. Dlugosz. Historiae Polonicae libri XII, t. 3, s. 20-21).

84 Petri de Dusburg Chronicon terrae Prussiae // SRP, 1861, Bd. 1, s. 157; Di Kronike von Pruzinlant des Nicolaus von Jeroschin // SRP, 1861, Bd. 1, s. 534-535 (lin. 19975-19977).

85 Błaszczyk G. Dzieje stosunków polsko-litewskich..., s. 54; Aścik K. Najazd litewski na Łęczycę w 1294 r., s. 11. 
kos, manevrų ypatumų ${ }^{86}$, tačiau šiuo argumentu suabejota, nes kovų su lietuviais istorija nėra tik vienas mūšis, o nemažai ịvairių susidūrimų, kurių metu buvo susipažinta su priešų karybos bruožais ${ }^{87}$. Hipotetinė galimybė, paremianti K. Aściko hipotezę, būtų lietuvių nulipimo nuo žirgų, bandant prisitaikyti prie aplinkos sąlygų, aspektas. Tokiu būdu iš tiesų buvo galima ivilioti priešininką kautis ì pelkètus paupius, tačiau Vytenio pajègos, kaip mus informuoja Petras Dusburgietis, netikètai smogè pirmosios, nesitikint Kazimierui II, todèl menka tikimybè, kad Vytenio kariai būtų pasiruošę tai daryti pésti, o ne raiti. Tad ir lenkų pralaimejjimo priežastis yra gana paprasta - jie buvo užpulti netiketai. Juo labiau kad nèra visiškai aišku, kaip lenkų istorikas suprato lietuvių karybos taktiką, ir apskritai - ar gerai išmanė ịvairius Lietuvos karybos aspektus ir probleminius klausimus, ar turẻjo pakankamai žinių, pavyzdžiui, apie kavaleriją, ginkluotę, šarvuotę.

Diskusija šiuo klausimu palietė dar vieną svarbų mūšio situacijos aspektą. Ar Boleslovo II vaidmuo nebuvo kertinis, padedant Vyteniui pasiekti pergalę? S. Zajączkowskis teisingai pažymèjo, kad didžiulis karinių pajėgų skirtumas ( 800 ir 1800 - veikiausiai padidinti skaičiai) galejo lemti lengvą lenkų pergalę, tačiau laiku įsikišęs Boleslovas II iš esmès sugebejo pakeisti visą situaciją, kai taip laimèjo laiko ir leido Vyteniui užimti puolančiųjų padèti. Jeigu Boleslovo II motyvas buvo toks, kaip teigia S. Zajączkowskis, tada Petro Dusburgiečio pateikti skaičiai, tiksliau - santykis, atrodo yra galimi, atsižvelgiant $\mathfrak{i}$ tai, kad tai buvo grobiamasis žygis, kuriame nebuvo siekiama susidurti su priešo kariuomene, o tiesiog greičiau pasitraukti. Tokiam manevrui atlikti reikejjo judrių pajègų, tad ir mažiau žygiuojančiųjų.

Svarbus šio mūšio aspektas - jo dalyviai, tiksliau - Vytenio pajègos. Kaip jau minèta, J. Długoszas teigia, kad Vytenis žygiavo su lietuviais, prūsais ir žemaičiais. Prūsų dalyvavimą žygyje vertintume labai atsargiai, neatmesdami versijos, kad J. Długoszo Pruthenis galima įvardyti greičiau kaip Ruthenis, atsižvelgiant $\mathfrak{i}$ tai, kad žymiojo istoriko epochoje, XIII a., buvo suvokiamas miglotai. Lygiai taip pat abejonių kelia žemaičių dalyvavimas, nes Vytenio valdymo laikais žemaičių konfrontacija su Lietuvos valdovu dèl jo vykdomos politikos buvo aršesnè. Vytenis žygi pradẻjo veikiausiai

86 Ten pat, s. 11.

87 Zajączkowski S. W sprawie najazdu litewskiego na Łęczycę w 1294 r., s. 328; Błaszczyk G. Dzieje stosunków polsko-litewskich..., s. 55. 
iš Gardino ${ }^{88}$, o Gardinas buvo etniškai mišresnis ir, kaip parodè $1311 \mathrm{~m}$. Voplaukio mūšis, iš ten su kunigaikščiu žygiuodavo rusų šauliai, kurie prireikus paremdavo Lietuvos didžiojo kunigaikščio karines pajėgas ${ }^{89}$. Jau nuo Traidenio valdymo laikų (1268-1282 m.) matome rusų šaulių pajègas, kariaujančias išvien su Lietuvos valdovu. 1274 m. datuotame nesèkmingame Daugpilio pilies šturme jie paremė Traideni $i^{90}$ XIV a. rusų šauliai, nuolatiniai lietuvių palydovai kovose, buvo sudarę atskirus pulkus ${ }^{91}$.

\section{BAIGIAMOSIOS IŠVADOS}

1. Atsižvelgiant $\mathfrak{i}$ istoriografijoje paplitusị $1294 \mathrm{~m}$. žygio kaip grobiamojo vertinimą, keltume hipotezę, kad pirminė Vytenio žygio kryptis buvo Vokiečių ordino Kulmo žemè, kurią jis siekè nusiaubti, tačiau,

\footnotetext{
88 Zajączkowski S. W sprawie najazdu litewskiego na Łęczycę w 1294 r., s. 324.

89 Dediala R. 1311 m. Voplaukio mūšis: priežastys, eiga, karybos aspektai, istorinè atmintis // Karo archyvas, 2015, t. 30, p. 29-30, 35-40.

90 Eiliuotoji Livonijos kronika, iš senosios vokiečių kalbos išvertẻ kanauninkas Pranciškus Žadeikis. Vertimą patikslino, suredagavo ir paaiškino Rimvydas Petrauskas // Mindaugo knyga: istorijos šaltiniai apie Lietuvos karalių. Vilnius, 2005, p. 314 (eil. 82168219); Livländische Reimchronik. Hrsg. von Leo Meyer. Paderborn, 1876, s. 188: „Rûzen schzutzen waren komen / kunige Thoreiden zû vromen. / sie wunten manchen mit ir bogen, / doch wurden sie dar an betrogen: / we ûf der burge wart gewurt / der wart schîre gesunt."
}

91 Di Kronike von Pruzinlant des Nicolaus von Jeroschin // SRP, Bd. 1, s. 577 (lin. 2369523702): „[...] Sô drang un uf di sîte / brûdir Gunther von Arnstein / mit des heris roten ein / kegn den rûsichen schutzin, / di kegn in benutzin / ouch in den zîten pflôgin / vil vîentlich ir bogin / und ire scharfen pfile [...]“ (1311 m.); Die Chronik Wigands von Marburg // SRP, Bd. 2, s. 511-512: „Rex vero convocat magnum exercitum, in quo vocati interant Ruteni de Lademer, de Brisik, Wytenberge, de Smalentz, vulgariter de Plosczkow etc. [...] Pagani cum lanceis suis jacerunt in christianos, Rutheni cum arcubus etc., telis multos vulnerantes viros et equos etc.“ (1348 m.); Die Chronik Wigands von Marburg // SRP, Bd. 2, s. 534: „[...] per quod chrisrianis sagittis multa mala facta sunt, introitum quorum potenter defenderunt.“, ten pat, s. 536: „Interim quidam Rutenus nomine Michael venit de domo, adducens mensuram sagittarum [vulgariter selpschosse]. Et quidam bayoribus nomine Gilgut Genehutte retulit, quomodo in castro angustias ferrent magnas et sine tedio fabricarent tela etc., spretantes domum defensare." (1362 m.) 
kryžiuočių žvalgams sužinojus šiuos tikslus, Vytenio pajègos patraukẻ ị Lenčycos žemę per Mazoviją, Boleslovo II valdas. Sekminès buvo patogus laikas netikètam smūgiui suduoti.

2. Egzistuoja dvi Vytenio žygio maršruto versijos. Pirmojoje teigiama, kad žygiuota per Boleslovo II valdas, o Vyslos upé pereita tarp Plocko ir Vyšegrado. Tada palei Bzuros upę nueita iki Lenčycos. Antroji skelbia, kad Vytenio maršrutas prasidejo Nemuno kirtimu, toliau žygiuota pasienio miškais tarp Lietuvos, Prūsijos ir Mazovijos. Paskui prie Zakročymo persikelta per Vyslą, vèliau prie Trojanovo - per Bzurą, o tarp Sabotos ir Valevičiu - i dešinijji Bzuros krantą, atsidurta ant Lovičiaus-Tumo kelio ir juo nužygiuota iki Lenčycos. Esminis istoriografinès diskusijos klausimas prie Vyšegrado ar Zakročymo buvo Vyslos perejimo vieta?

3. 1294 m. per Sekmines (birželio 6-7 d.) Vytenio vadovaujamos pajègos ịsiveržè ị Lenčycos kunigaikštystę ir ją nusiaubẻ. Lenčycos kunigaikštis Kazimieras II su gausiomis pajègomis pasivijo atsitraukančias Vytenio pajègas prie Bzuros upès, Trojanovo ir Žukovo apylinkèse.

4. Mazovijos kunigaikštis Boleslovas II įsikišo tarp dviejų kariaujančių šalių ir tarpininkaudamas sudarè laikinas paliaubas, kurios leido Vytenio pajègoms persigrupuoti ir užsiimti geresnę puolimo poziciją. Neabejotinas Boleslovo II palankumas lietuviams matyti ir tolesniuose veiksmuose.

5. $1294 \mathrm{~m}$. birželio 9 ar $10 \mathrm{~d}$. šias paliaubas lietuviai nutraukè ir netikètai užpuole nepasiruošusius Kazimiero II karius. Pirmųjų smūgis tapo pergalès priežastimi. Taip įsiplieskẻ kautynès prie Trojanovo. Jos, remiantis istorikų hipotezèmis, ịvyko naktị, pelkių ir miškų apsuptyje, dešiniajame Bzuros krante. Taip Vytenio pajègos sutriuškino Kazimiero II pajègas. Šaltinių duomenimis, liko gyvas tik vienas lenkų karys. Istoriografijoje šis susidūrimas vertinamas kaip didžiausias lenkų pralaimẻjimas lietuviams (1800 susikovus su 800 karių).

6. Abejotina J. Długoszo žinia, kad žygyje dalyvavo prūsai ir žemaičiai. Greičiausiai žygis buvo surengtas lietuvių ir rusų pajègų (tikètina, šaulių ir kt.), kurios galėjo prisijungti nuo Gardino, spejjamos žygio pradžios vietos. 
LIETUVOS DIDŽIOSIOS KUNIGAIKŠTYSTĖS KARIUOMENE்

\section{PRIEDAI}

\section{1 priedas}

1294 m. Vytenio pajėgų žygio maršruto schema pagal Kazimierzą Aściką

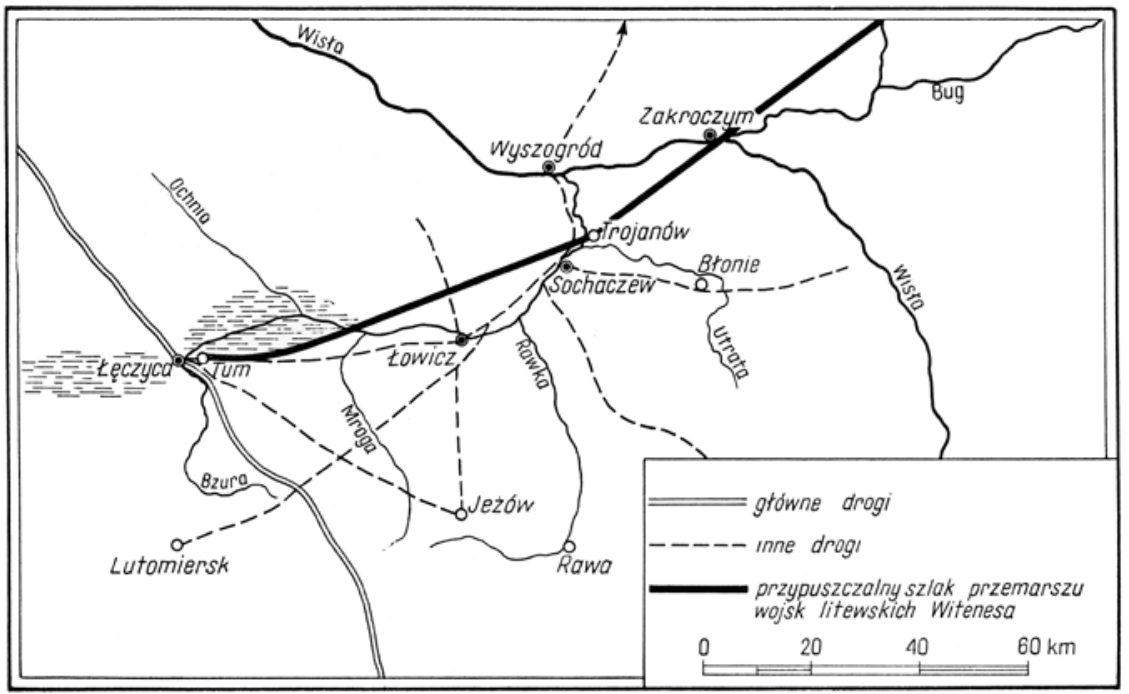

Šaltinis: Aścik K. Jeszcze raz o najeździe litewskim na Łęczycę // Studia i materiały do historii wojskowości, 1969, t. 15, cz. 1, s. 318 


\section{2 priedas}

Lenkijos žemės XIII a. pab., 1294 m. Vytenio žygio maršrutas ir mūšio vieta pagal Janą Szymaczką

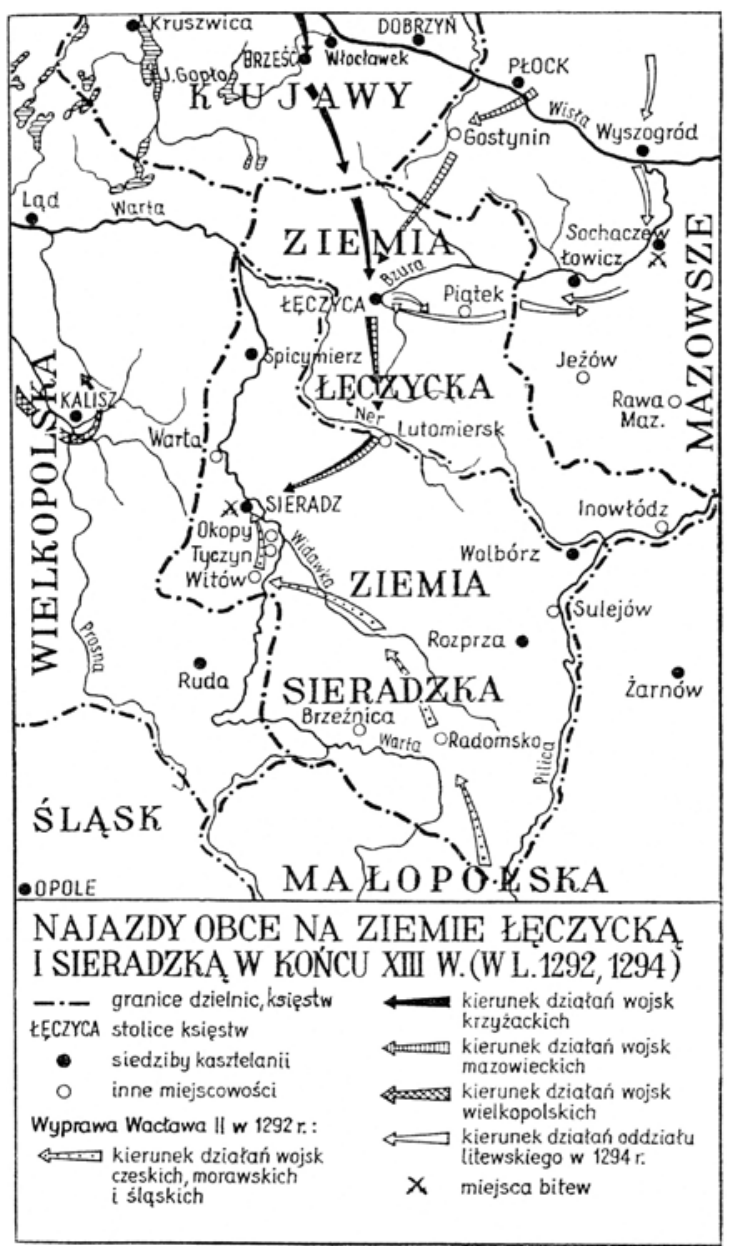

Šaltinis: Szymaczak J. Ziemia łęczycka i sieradzka terenem działań wojennych w XII i XIII wieku // Rocznik Łódzki 1975, t. 20(23), s. 222 (mapa 3) 


\section{3 priedas}

Svarbiausi $1294 \mathrm{~m}$. Trojanovo mūšio šaltiniai

Pastaba. Skelbiami ne visi tekstai, kuriuose minimas $1294 \mathrm{~m}$. ìvykęs mūšis. Apsiribojama svarbiausiais Trojanovo mūšio šaltiniais, kurie skaitytojui sunkiau prieinami. Dauguma vèlesnių tekstų, kuriuose minimas mūšis, yra išversti ị lietuvių kalbą ir nesunkiai pasiekiami. Šaltiniai skirstomi ị 3 grupes pagal kilmę:

\section{1) Vokiški šaltiniai}

Petri de Dusburg. Chronicon terrae Prussiae | Petras Dusburgietis. Prūsijos žemès kronika

Eodem anno Vithenus filius regis Lethowie cum octingentis viris intravit terram Polonie, et in die pentecostes, dum in ecclesia Lunczensi canonici et ministri altaris et alii clerici cum solempni ornatu essent in processione, irruit hostiliter in eos, et in ecclesia cccc homines cristianos trucidavit, clericos et prelatos, quos voluit, captivos secum duxit, omnem ornatum, calices et alia visa ecclesie ad illicitum usum pertrahebat in contemptum dei ecclesiam cum sacramentis redegit in favillam, depopulataque terra circum adjacente factaque maxima strage in populo dei, tantam multitudinem deduxit captivam, quod cuilibet lethowino in divisione cesserunt xx homines cristiani. Quo facto dum recederent, Casimirus dux Polonie dolens de suorum interitu, cum mille et octingentis viris sequutus est eos. Quod dum perciperet Bonislaus dux Masovie || nescio quo ductus spiritu, treugas inter Cristianos et infideles ad certum terminum ordinavit, infra quas dum Poloni nihil timentes diversis officiis vacarent, Lethowini rupto treugarum federe, irruerunt in eos, et Casimirus ducem et totum populum permerunt, preter unum militem, qui evasit solus, ut hec aliis nunciaret ${ }^{92}$.

Di Kronike von Pruzinlant des Nicolaus von Jeroschin | Mikalojus Jerošinietis. Prūsijos žemès kronika

In den selbin zîten / von Littouwin Witen / den kungis sun an sich ge-

92 Petri de Dusburg Chronicon terrae Prussiae // SRP, 1861, Bd. 1, s. 156-157. 
wan / der sînen achtehundirt man / und abir kegn Polênen reit, / der reinin gotis cristinheit / zu jâmirlîchir pflâge, / und an dem pfingistage, / sich zu lobe gote / der tûmhêrrin rôte / und al dî andre pfafheit / gezîrit hatte und angelei / mit pfeflîchim ornâte / in lobelîchir vlâte / unde hîldin schône / dî processiône / in gotlîchim rûme / zu Lunczicz in dem tûme, / und daz gotis reine / cristnevolc gemeine / in andâcht hatte sich gesamt / zu hôrne daz gotis amt, / dô quam des tûvils bote în / gesprengit mit dem here sîn / sundir vorwarnunge gar / unde slûc der cristninschar / in der kirchin dâ mit nôt / wol vîrhundirt mensche tôt; / doch pfaffin und prêlâtin, / dî daz gelucke hâtin, / er gevangin nam ein teil, / daz sî achtin vor ein heil, / want in daz lebin alsô bleib, / und dî mit im von dannen treib. / Kelche, mesgewête / und alle daz gerête, / daz gote was gewîet / und in sîn dînst gevlîet, / nam der ungenême / und in ungezême / ûbunge sî vorspente; / darzû dî sacramente, / der wir geistlîch hî waldin / und uns sint zu sâldin / in êwic pfant gewisse, / er gote zu smênisse / mit der kirchin vorbrante / und gar in asche wante; / darzû allirwegin / daz lant dâbî gelegin / vorherte unde machte toub / und nam ouch dâ vil grôzin roub / von mannin, kindin, vrouwin, / daz iclîchim Littouwin / geburte an der buite / zwênzic cristeneluite. / Dô hêr Kasimir gesach / der herzoge diz ungemach / und dî jâmirbernde nôt, / dî sich sînem volke bôt, / daz man hin vûrte in vorlust; / ein bittir zorn in sînre brust / mit leide sô irbolgete, / daz er den vîendin volgete, / dô sî zugin dannen, / mit achzênhundirt mannen. / Und dô er vaste bî sî quam / und daz Bonislaw vornam, / der herzoge von Masow, / inweiz welch geist in ummezow / und was in leitte ûf den sin, / wen daz er worchte zwischin in / vridde durch eine sûne / ûf eine benante lûne; / und dô dâbinnin sundir vâr / dî Polêne her und dar / sich von einandir strouweten, / dî Littouwin beschouweten / unde wârn âne wer, / dô hûb sich Witênis her / an sî den vridde brechinde, / slânde unde stechinde / in vîentlîchir gire / und dâ Kasemire / den herzogin slûgin tôt / und mit semelîchir nôt / sîn volke irmortin allintsam, / daz nî mensch, als ich vornam, / intquam der nôt sô bittir, / sundir ôt ein rittir; / den hôrte man sint wol vorjên, / wî den andrin was geschên ${ }^{93}$.

93 Di Kronike von Pruzinlant des Nicolaus von Jeroschin // SRP, 1861, Bd. 1, s. 534. 
2) Lenkiški šaltiniai

Rocznik franciszkański krakowski| Krokuvos pranciškonų metraštis

Quartum Kazimirum, qui Lanciciam possedit, qui et sine prole decessit, nam a Lythwanis in bello occiditur anno domini $1293^{94}$.

Rocznik miechowski| Miechovo metraštis

1295. Procopius epsicopus Cracoviensis obiit, Iohannes succedit. Eodem anno Litwani perimerunt multos cristianos. Ecclesia Lanczicziensis crematur. Kazimirus dux cum exercitu suo occiditur in Sochaczow ${ }^{95}$.

Rocznik Traski| Traskos metraštis

1294. Strages maxima facta est in militibus per Litwanos et dux Kazimirus, dux Lancicie, occiditur per eosdem ${ }^{96}$.

Rocznik małopolski| Mažosios Lenkijos metraštis

1294. Stranges maxima facta est in militibus per Lithuanos et dux Kazimirus, dux Lancicie occiditur per eosdem ${ }^{97}$.

Spominki gnieźnieński| Gniezno pastabos

Item Lancicia per Litwanos vastatur et ecclesia gravissime crematur anno 1304 die penthecostes. || Eodem anno quinta feria proxima post festum penthecostes fuit bellum cum Lithwanis in Troyanow et occiditur dux Kazimirus cum exercitu suo ex mala custodia ${ }^{98}$.

Rodowód xiążąt polskich | Lenkų kunigaikščių kilmės metraštis

Kazimirum ducem Lanciciensem, qui occisus est in bello a Lithwanis ${ }^{99}$.

Kronika xiążąt polskich | Lenkų kunigaikščių kronika

Genuit nihilominus Kazimirus, dux Coyavie supradictus Kazimirum occisum a Lithuanis et Semovitum ducem Dobrinensem, de quibus || heredes alios non invenio processisse ${ }^{100}$.

\footnotetext{
94 Rocznik franciszkański krakowski // MPH, 1961, t. 3, s. 47.

95 Rocznik miechowski // MPH, 1961, t. 2, s. 883.

96 Rocznik Traski // MPH, 1961, t. 2, s. 852.

97 Rocznik małopolski // MPH, 1961, t. 3, s. 186.

98 Spominki gnieźnieński // MPH, 1961, t. 3, s. 43-44.

99 Rodowód xiążąt polskich // MPH, 1961, t. 3, s. 283.

${ }^{100}$ Kronika xiążąt polskich // MPH, 1961, t. 3, s. 542-543.
} 
Ioannes Dlugossius. Annales seu cronicae incliti Regni Poloniae | Janas Długoszas. Garbingosios Lenkijos karalystès metraščiai arba kronikos

Annus Domini 1294. Withenen Dux Lithuaniae Lanciciam clandestine ingresus, ecclesiam collegiatam spoliat, domibusque incensis et eadem ecclesia conflagratur. Caede autem ingenti edita, dum cum praeda rediret, praelio conserto cum eo, Kazimirus Dux Lanciciae occiditur: cui in Ducatu Lanciciensi germanus suus Wladislaus Loktek succedit.

Non defuit et hoc anno divina indignatio, per rabiem barbaricam desaeviens in Polonos. Vithenen enim Lithuaniae Dux cum mille octingentis equitibus, ex Lithuanis, Pruthenis et Samagitis collectis, in Lanciciensem terram impetum fecit. Quam dum feria quinta Pentecostes per silvas et nemora, Duce Masoviae Boleslao permittente et favente, tam silenti et ignoto agmine, ut quislibet praetereuntes fallerent, ingressi fuissent, primum ad ecclasiam collegiatam Lanciciensem accurrunt, populique utriusque sexus praesentiam, qui illuc gratia celebrandi festi confluxerat, aut trucidant, aut captivant; praelatos, canonicos et sacerdotes Domini miseabiliter captivant, vestates sacras, vasa et clenodia diripiunt, caeteros, qui ad ecclesiam confugerant et in illa se viriliter defensabant, vicinis domibus quae ecclesiam circumstant, incensis, in ecclesiam Lanciciensem incendium inferentibus, suffocant et exstinguunt. Ad rura deinde et vicos discurrunt, et praeda plurima ex hominibus et pecore comparata, citato cursu redibant. Non tulit et suam et gentis suae calamitatem Kazimirus Lanciciensis Dux, sed cum singulis terrae Lanciciensis militibus barbaros persequi coepit. Quos cum in Zukov villa, prope oppidum Sochaczow supra fluvium Bszura sita, secundum alios circa villam Troyanow, consecutus fuisset, paucitate sui agminis et hostili multitudine minime pensata, in barbaros irruit. Et magna strage edita, multisque captivis per fugam fervente praelio elapsis, a multitudine barbarica victus, succumbit, et inter consertissimos hostes audacissime inter primos pugnans, nobilem excipit mortem. Quo occidente, fuga passim per Polonos fieri ceopta est, et plures ex Polonis, dum mortem honestam vitant, in mortem turpem incidunt et in flumine Bszura, ultra quod pugnatum est, aquis plus tunc solito ex imbribus inflatis, submerguntur. Lithuani et praeda et victoria potiti, eam tunc ex captivis Polonis praedam asseruntur retulisse, et culibet barbaro viginti Christiani Poloni in sorte cesserint. Non reliquit Kazimirus Lanciciensis Dux aliqu- 


\section{LIETUVOS DIDŽIOSIOS KUNIGAIKŠTYSTĖS KARIUOMENE்}

em superstitem, propter quod Lanciciensem terram || Wladislaus Loktek Cuyaviensis Dux germanus suus, legitime in se devolutam accepit ${ }^{101}$.

1) Rusiški šaltiniai

Густинская летопись | Gustyno metraštis

Въ льто 6802 (1294). Витенесъ, великій князь Литовскій, воюетъ Ляховъ; и Казимера князя Ленчицкого порази и уби ${ }^{102}$.

Iteikta 2015 m. spalio $14 \mathrm{~d}$.

${ }^{101}$ Jan Dlugosz. Historiae Polonicae libri XII, t. 2, s. 520-521.

102 Густинская летопись // ПСРЛ, 1843, т. 2, с. 348. 


\title{
LA BATAILLE DE TROJANOW EN 1294
}

\author{
Ričardas Dediala \\ Université de Vilnius
}

Lépoque de Vytenis, tout comme la seconde moitié du XIIIe siècle et le début du XIVe siècle, n'est pas connue pour de violents affrontements avec les princes des terres polonaises, et en 1306 ceux-ci ont pris complètement fin et nont repris que pendant le règne de Gediminas, lorsque la situation politique a changé. Vytenis (règne 1295-1315), fils du grand-duc Butvydas, a commencé sa carrière politique notamment par des attaques des terres polonaises. Lors d'une de ses premières campagnes, il s'est heurté à une grande armée polonaise. Cet affrontement militaire de 1294 a reçu le nom de Trojanów et eu un grand retentissement dans les sources historiques. Cela a été une des trois batailles les plus grandes (Trojanów, Turaida, Woplauken) de lépoque de Vytenis. Cet écho des sources a été inspiré par la mort du prince Casimir II de Łęczyca (frère du futur roi de Pologne Ladislas Ier le Bref) sur le champ de bataille. Selon une hypothèse, la direction initiale de la campagne de Vytenis était la terre de Kulm de l'Ordre des chevaliers teutoniques qu'il cherchait à dévaster, mais, après que les éclaireurs des chevaliers teutoniques aient eu connaissance de ces objectifs, les troupes de Vytenis ont pris la direction de la terre polonaise de Łęczyca à travers la Mazovie, territoire de Boleslas II qui soutenait à l'époque les Lituaniens et leur permettait d'utiliser le château de Wizna. La Pentecôte était une bonne période pour une attaque inattendue. Dans l'historiographie polonaise se sont formées deux versions de l'itinéraire de la campagne de Vytenis, dont la différence essentielle est le lieu de franchissement de la Vistule (près de Wyszogród ou Zakroczim). En 1294, pendant la Pentecôte (6-7 juin), les troupes commandées par Vytenis ont envahi le duché de Łęczyca et l'ont dévasté. Le prince de Łęczyca Casimir II a rattrapé avec de nombreuses troupes les forces en retraite de Vytenis près de la rivière Bzura, dans les environs de Trojanów et Żukowo. À cause de l'intervention du prince de Mazovie Boleslas II entre les deux adversaires, 
un regroupement supposé des forces de Vytenis a eu lieu, ce qui leur a permis d'occuper une meilleure position d'attaque. Le 9 ou 10 juin 1294, les Lituaniens ont violé cet armistice et attaqué par surprise les soldats de Casimir II qui nétaient pas prêts. Une bataille a ainsi commencé près de Trojanów. En se basant sur les hypothèses des historiens, elle a eu lieu la nuit, parmi les marécages et les forêts, sur la rive droite de la Bzura. Les troupes de Vytenis ont écrasé l'armée de Casimir II. Selon les sources, seul un soldat polonais survécut. Dans l'historiographie, cet affrontement est jugé comme la plus grande défaite polonaise contre les troupes militaires lituaniennes. 


\title{
THE BATTLE OF TROJANOW IN 1294
}

\author{
Ričardas Dediala \\ Vilnius University
}

The reign of Vytenis, just like the second half of the thirteenth century and the beginning of the fourteenth century, was not characterised by great conflicts with the dukes of Polish lands; they ended in 1306, and only recommenced during the reign of Gediminas when the political situation changed.

Vytenis (who ruled from 1295 to 1315), the son of the Great Duke Butvydas, began his political career by attacking the Polish lands in particular. During one of the first marches, he was faced with a large Polish army. This military confrontation in 1294 was known by the name of Trojanow, and had a resonant echo in historical sources. It was one of the three (Trojanow, Turaida, Voplaukis) greatest battles of the period of Vytenis. The echo of sources was inspired by the death of Duke Casimir II of Leczyca (the brother of the future King of Poland Vladislav Lokytek) on the battlefield. There is a hypothesis that the primary direction of the march of Vytenis was the Kulmer land of the Teutonic order seeking to devastate it. However, when the spies of the crusaders revealed his intentions, the forces of Vytenis turned to the Polish Leczyca land through Mazovia, the holdings of Boleslov II, who at that time supported the Lithuanian forces and allowed the use of Wizna castle. Pentecost was a convenient time to strike an unexpected blow. Two versions of the Vytenis march were provided in the Polish historiography with the essential difference being the place where he crossed the Vistula (Wisla) River (near Visegrad or Zakroczym). In 1294, on Pentecost (June 6-7), the forces led by Vytenis invaded the Duchy of Leczyca and devastated it. Duke Casimir II of Leczyca with large armed forces caught up with the retreating army of Vytenis near the Bzura River, in the surroundings of Trojanow and Zhukov. Due to the intervention of Duke Boleslaw II of Mazovia, the regrouping of Vytenis' armed forces took place between the two opponents, which 
allowed them to better their attack position. On the 9th or 10th of April 1294, the Lithuanians ended the truce and launched an unexpected attack on the unprepared soldiers of Casimir II. This was the battle that occurred at Trojanow. Based on historical hypotheses, it took place at night, in the surroundings of marshes and forests, on the right bank of the Bzura. The forces of Vytenis defeated the troops of Casimir II. According to sources, only one Polish soldier survived. In historiography, this confrontation is assessed as the biggest defeat of the Polish army by the Lithuanian armed forces. 